\title{
Effect of soaking on physical functional and cooking time of cowpea, horsegram and mothbean
}

\author{
C.K. Bhokre and A.A. Joshi
}

\begin{abstract}
The effect of different soaking media on physical parameter such as hundred seed weight, bulk density, density, functional characteristics viz., hydration capacity, swelling capacity and cooking time of cowpea, horsegram and mothbean were studied. The study was carried out in year 2014 at the college of Food Technology Vasantrao Naik Marathwada Krishi Vidyapeeth Parbhani. The seeds were soaked in three different solution at room temperature viz., normal drinking water $\left(\mathrm{T}_{1}\right), 1$ per cent $\mathrm{NaCl}$ solution $\left(\mathrm{T}_{2}\right)$ and 1 per cent $\mathrm{NaHCO}_{3}$ solution $\left(\mathrm{T}_{3}\right)$ separately for $12 \mathrm{hr}$ and one was kept untreated $\left(\mathrm{T}_{0}\right)$. In cowpea significant increase in hundred seed weight from $6.82 \mathrm{~g}\left(\mathrm{~T}_{0}\right)$ to $9.40 \mathrm{~g}\left(\mathrm{~T}_{1}\right), 9.54\left(\mathrm{~T}_{2}\right)$ and $10.54 \mathrm{~g}\left(\mathrm{~T}_{3}\right)$ was found. Similar results observed for horsegram and mothbean of significant increase in Hundred Seed Weight after soaking. The highest bulk density $\left(0.633 \mathrm{gml}^{-1}\right)$ was observed in cowpea seeds soaked in sodium bicarbonate solution $\left(\mathrm{T}_{3}\right)$ compared $\mathrm{T}_{2}\left(0.622 \mathrm{gml}^{-1}\right)$ and $\mathrm{T}_{1}\left(0.59 \mathrm{gml}^{-1}\right)$. Likewise in cowpea density of $\mathrm{T}_{0}$ was significantly highest $\left(1.24 \mathrm{gml}^{-1}\right)$ followed by $\mathrm{T}_{3}\left(1.05 \mathrm{gml}^{-1}\right)$ and $\mathrm{T}_{2}\left(0.95 \mathrm{gml}^{-1}\right)$. The similar trend of decrease in bulk density and density compared to samples without soaking was observed in mothbean and cowpea. The $\mathrm{T}_{3}$ sample gave significantly higher hydration capacity $0.037 \mathrm{~g} \mathrm{seed}^{-1}$ of cowpea, $0.055 \mathrm{~g} \mathrm{seed}^{-1}$ of horsegram and $0.027 \mathrm{~g} \mathrm{seed}^{-1}$ of mothbean than $\mathrm{T}_{2}$ and $\mathrm{T}_{1}$ in all three legume. In cowpea the soaking treatment did not show significant difference in swelling power for $\mathrm{T}_{2}\left(0.045 \mathrm{~g} \mathrm{seed}^{-1}\right), \mathrm{T}_{3}$ $\left(0.045 \mathrm{~g} \mathrm{seed}^{-1}\right)$ and $\mathrm{T}_{1}\left(0.044 \mathrm{~g} \mathrm{seed}^{-1}\right)$. While sample $\mathrm{T}_{3}$ had maximum value for swelling power in both horse gram $(0.50$ gseed $\left.^{-1}\right)$ and mothbean $\left(0.035 \mathrm{~g} \mathrm{seed}^{-1}\right)$ compared to $\mathrm{T}_{2}$ and $\mathrm{T}_{1}$ treatment. Soaking study revealed that there is significant reduction in cooking time of three legume soaked. For cowpea the treatment $\mathrm{T}_{1} \mathrm{~T}_{2}$ and $\mathrm{T}_{3}$ showed 51.42 per cent, 65.71 per cent and 85.71 per cent reduction in cooking time, respectively compared with unsoaked seed samples $\left(\mathrm{T}_{0}\right)$. In horsegram the soaking treatment $\mathrm{T}_{3}, \mathrm{~T}_{2}$ and $\mathrm{T}_{1}$ had 45.45 per cent, 30.90 per cent and 12.72 per cent decrease in cooking time, respectively. Similarly in mothbean decrease in cooking time of $\mathrm{T}_{3}(80 \%), \mathrm{T}_{2}(50 \%)$ and $\mathrm{T}_{1}(20 \%)$ was found . Among three legume the lowest cooking time recorded in mothbean followed by cowpea and horsegram.
\end{abstract}

Key Words : Cowpea, Cooking time, Functional attributes, Horsegram, Moth bean, Physical properties

How to cite this article : Bhokre, C.K. and Joshi, A.A. (2015). Effect of soaking on physical functional and cooking time of cowpea, horsegram and mothbean. Food Sci. Res. J., 6(2): 357-362.

Author for correspondence :

A.A. JOSHI, Department of FCN, College of Food Technology, Vasantrao Naik

Marathwada Krishi Vidyapeeth, PARBHANI (M.S.) INDIA

Email : lakha02-cft@rediffmail.com

Associate Authors' :

C.K. BHOKRE, Department of FCN, College of Food Technology, Vasantrao

Naik Marathwada Krishi Vidyapeeth, PARBHANI (M.S.) INDIA 